\title{
Children born of War and Social Trust - Analysing Consequences of Rejection
}

\author{
Andrea Meckel, ${ }^{1 *}$ Ingvill C. Mochmann, ${ }^{12}$ Bogdan Voicu, ${ }^{34}$ Martin \\ Miertsch $^{5}$
}

${ }^{1}$ GESIS-Leibniz Institute for the Social Sciences, Unter Sachsenhausen 6-8, 50667 Cologne, Germany

${ }^{2}$ Cologne Business School, Hardefuststraße 1, 50677 Cologne, Germany

${ }^{3}$ Romanian Academy, Research Institute for Quality of Life, 13 Calea 13 Septembrie, 050711 Bucharest, Romania

${ }^{4}$ Lucian Blaga University of Sibiu, Sociology and Social Work Unit, 2A, Lucian Blaga Street, 550169 Sibiu, Romania

${ }^{5}$ University Medicine Greifswald, Department of Psychiatry and Psychotherapy, HELIOS Klinikum Stralsund, Fleischmannstraße 8, 17475 Greifswald, Germany

KEYWORDS

Children Born of War

Social Trust

SEM

Norway
ABSTRACT

This article examines the question whether rejection experiences negatively relate to the social trust of Children Born of War (CBOW) and if this connection is mediated by sense of self-worth. $\mathrm{CBOW}$ is a group of people born out of relations during war- and post-war times, involving one parent being a foreign soldier, a para-military officer, rebel or other person directly participating in the hostilities, while the other parent is a member of the native population. Also children born to child soldiers and children fathered by members of a peacekeeping troop are included within this group. These children, due to their biological background, often grow up in a surrounding in which they are perceived as child of the enemy. The general hypothesis is that, due to their exposure to rejection experiences by their caregivers as well as by the society, CBOW are less likely to develop trust. It is further assumed that this relationship is mediated by the sense of self-worth. A structural equation model was applied to test the relation using a sample of Norwegian children born of war. Results indicate that $\mathrm{CBOW}$ who experience rejection share a lower sense of self-worth, which is further connected to lower trust, whereas no direct association between rejection experiences and trust was found.

*Contact address: andrea.meckel@gesis.org (A. Meckel) 


\section{Introduction}

In recent decades, the study of trust has become increasingly popular within the social science community (Hardin 2006; Welter 2012). At a societal level, it has been seen as catalyst for social and economic development (Bjørnskov 2012), as prerequisite in producing public goods (Putnam 1994), as a basis for social cohesion (Larsen 2013), and as buffer against corruption (Rothstein 2013). Also at the individual level it has been assigned importance. For example, it has been found to increase child wellbeing (Ferguson 2006), to be the basis for entrepreneurship (Welter 2012) and to increase education achievements (Goddard 2003). Trust, and especially generalized or social trust, is considered as a key prerequisite for cooperative behaviour and in the long run is assumed to be a factor for the developmental possibilities of people and societies as a whole (Misztal 2013).

Trust is at least in parts assumed to be rooted in experiences from early childhood (Uslaner 2002). Within cultures of trustworthiness, norms of trust are internalized from a young age and used as life-long benchmarks (Voicu 2014), reaching even to second generation descendants (Uslaner 2002). Therefore, growing up in an environment of constant mistrust - a likely circumstance during war and post-war times (Voicu and Mochmann 2014: 198) - is seen as a problematic issue. This situation might negatively affect the trust and attachment behaviour of children growing up in (post-) war societies throughout their whole lives and possibly lead to a smaller social network also during adulthood (Barenbaum, Ruchkin and SchwabStone 2004; Voicu and Mochmann 2014). Among many groups who live through war and post-war periods, there is one group that is specifically likely to be confronted with a mistrusting environment in post-war communities: Children Born of War (CBOW) characterizes those born as a consequence of a war or war-like conflict where one parent usually is a member of an army or peacekeeping force and the other a local citizen 
(Grieg 2001: 6; Mochmann 2006)..$^{1}$ This particular group will be the focus of this article. As a constant reminder of the traumatic war experience $\mathrm{CBOW}$ often face rejection, exclusion and stigmatization by the society and even by their own family2. In cases when their parent is member of an army labelled as 'the enemy', CBOW often also bear the stigma of 'belonging to the enemy' (Kleinau and Mochmann 2016). Consequently, they might not only grow up in a context of mistrust, but experience hostility and mistrust which is specifically directed to them due to their biological background (Meckel, Mochmann and Miertsch 2016; Voicu and Mochmann 2014).

While these children certainly have been and will be the result of any war over the history of mankind, research on children in post-war communities has until now only seldom specifically addressed this group (Ericsson and Simonsen 2005; Mochmann et al. 2009). Within the last decade, however, interests in this research field has increased and researchers from various disciplines are now trying to gain a better understanding of CBOW's lives and the consequences (Mochmann 2017). However, the topic of social trust of CBOW was hardly ever, and never directly, addressed (see Voicu and Mochmann 2014 for a summary).

In the general literature on trust various assumptions on how social trust is formed are discussed. One important paradigm finds the main source of social trust in the generalization of one's social interactions (e.g. Luhmann 1979). If exposed to negative interaction experiences, a CBOW is expected to develop lower social trust. These experiences might also affect trust indirectly through the development of a low sense of self-worth. Being stigmatized and feeling suspicion in the eyes and behaviours of others during regular encounters might lead the child to the conclusion that something is wrong with him- of herself and that he or she is less worthy as compared to others (Meckel, Mochmann and Miertsch 2016). The sense of

\footnotetext{
${ }_{1}^{1}$ Grieg uses the concept 'war child' to address this specific group - however, in 2006 the research community agreed to consequently apply the concept 'children born of war' to address this particular group of children as 'war child' already had specific meanings in several countries and cultures (cf. Mochmann 2006).

2 This equally applies to families of the mothers and the fathers, as well as to potential adoption families.
} 
self-worth and feeling as being an accepted part of the society should play a key role in expecting strangers to be trustworthy towards the own person, leading those with lower sense of self-worth to trust less.

This article examines the question whether CBOW's rejection experiences negatively influence their social trust and if this connection is mediated by the sense of self-worth. To that respect, a distinction between rejection experiences by caregivers and by the society is made. The paper is based on a former article by Voicu and Mochmann (2014) who developed theoretical assumptions on $\mathrm{CBOW}$, trust and its importance for post-war societies. With this article, we will go further and empirically test the assumed relationship. The general hypothesis is that due to exposures to rejection CBOW are likely to manifest a low sense of self-worth and consequentially a lower social trust. A structural equation model is applied testing the supposed relations using a sample of Norwegian CBOW.

\section{Children Born of War}

Mochmann (2008: 55-56) categorizes CBOW in four groups, namely (1) children of enemy soldiers, (2) children of occupying soldiers, (3) children of child soldiers and (4) children of members from peace keeping troops. While not exhaustive, these categories give a broad clustering of the groups of CBOW that exist. By eliciting these groups Mochmann (2008) already extended the original definition by one further group: the children of child soldiers do not necessarily have one parent who is member of a foreign army (or a peacekeeping troop). Thus, note that the term 'Children Born of War' also refers to children with a parent who is a member of a military or paramilitary organization within the country. However, there must be a war or war-like conflict, to create the societal setup in which one of the parents is defined by others as part of the 'adversaries' and where the offspring is suspected to belong to the 'enemy' (Mochmann and Kleinau 2016).

This creates a double context that is of importance for social interactions that shape social trust. On one hand, there is a specific context of 
uncertainty - the war. Conflagrations bring times when one cannot easily predict what will follow and how others will behave in regular interactions. On the other hand, CBOW are directly associated with the war and in many cases with the enemy. Going beyond the general mistrust likely during (post-) war times, stigmatization and mistrust may be specifically directed towards these children. As we explain in the next section, both circumstances are likely to decrease social trust.

\section{Theoretical background and development of hypotheses}

\section{Why Social Trust?}

Trust generally describes the positive expectation one holds of the actions and intentions of others (Möllering 2001: 404). Depending on the perspective and the research interest the target of trust might differ. Specifically, there is a distinction between particularized trust, further described as the trust given to a specific person or group, and social trust, targeting people in a more general fashion. For our purposes, we concretely focus on the latter.

As outlined before, many authors assign trust, and in specific social trust, a very high relevance. As such it is regarded as a main component of social capital (Putnam 1995) and the basis to enable fruitful and positive social interactions (Uslaner 1999; Glanville and Paxton 2007). In everyday life people often need to interact and cooperate with strangers. People who trust strangers are able to cooperate directly and without hesitations. This not only saves time and reduces interaction costs (Luhmann 1979) but also enables people to widen their social network beyond the boundaries of their own groups. Thus, trust can be seen as highly important, especially with regard to the crucial task of 're-starting the engine of development' (Voicu and Mochmann 2014: 203) in the reconstruction phase after a war. 


\section{Sources of Social Trust}

There are two prominent theoretical perspectives on the origin of social trust in the current literature (Glanville and Paxton 2007: 231). On one hand, trust is regarded as a somewhat 'sticky and static' personality trait which develops during a very early stage of childhood or is even partially due to genetics. On the other hand, trust is interpreted as constant lifelong learning modulating continuously existing expectation - a dynamic trait. Both perspectives can be assumed to be valid (Bekkers 2012).

From a different viewpoint, a rational perspective can be adopted, to interpret trust as a kind of 'rational bet' on the trustworthiness of others (Uslaner 1999; Ermisch et al. 2009; Frederiksen 2012; Hardin 1999). Indeed, trust can hold strong benefits as long as the counterpart is also trustworthy. Ermisch et al. (2009) assume three components to be relevant in the decision of trusting another person: weighting benefits and costs; being willing to take a risk; and evaluating the likelihood of the other person being trustworthy.

There are different theoretical assumptions on how people come to this evaluation. From one perspective, in order to come to an evaluation on the trustworthiness of an unknown person people have to generalize their experiences and transfer them to similar situations (Luhmann 2014: 31). Experiences affecting trust can be of different kind: they can be concrete and single incidents (e.g. the betrayal of a friend) or constantly recurring (e.g. constant rejection). Further, they can also only indirectly concern a person, as e.g. social conflicts in a society (Delhey and Newton 2003). The level of social trust within the society might as well be seen as such an experience. If most people are trusting this might be an incentive for trust and vice versa (Voicu 2014: 3).

Hardin (1999) has introduced a different perspective of trust, understanding it as an expression of encapsulated interests: A person (A) trust another person (B) to act in ones' interests because $B$ has good reasons to do so. These reasons are connected to the own person of A (Hardin 1999: 
26) and can be for example a relationship between A and B, which B does not want to endanger or resources of $A$ which $B$ wants to access. This approach builds on the assumption that, short or long-term, there will be some kind of repayment of being trustworthy. Following this perspective, it would be reasonable to trust, if the trusted person believes that B has an interest in the own person or ones' resources.

Moreover, Simmer (1950: 340), later taken up and discussed by Uslaner (2002), come to the conclusion that trust is a moral value with an almost compulsory power. Betraying the trust, a person 'requires thoroughly positive meanness'. If trustworthiness is, in fact, a moral value, it should, as a general rule, be advantageous to trust. This would only then not be reasonable if a person believes to be excluded from this value or the predominant system of values in which it is valid. This might especially be true for people who see themselves at the edge of society.

These formerly described ways on how people come to an evaluation of the trustworthiness of others are clearly not mutually exclusive. Quite the contrary, it seems reasonable to assume that all of them are interacting with each other. E.g., the personal assessment of individuals and their respective position within their society is likely to be shaped by their experiences with others. Concerning this, Leary et al. (1995) show, for example, a causal relationship between exclusion experiences and trust in a series of experiments.

Derived from the above described theory we expect the following hypotheses, which are graphically shown in Figure 1:

H1: Negative experiences in interaction with others lead to low social trust.

$\mathrm{H} 2$ : This relation is partially mediated through the sense of self-worth. 
Figure 1. Conceptual Model

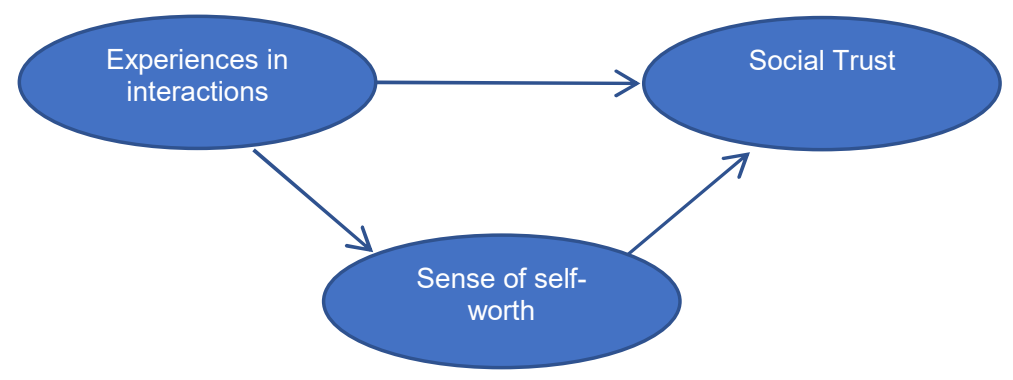

In the following, we specify the hypotheses to the CBOW situation, in particular considering the impact of rejection, and self-worthiness.

\section{CBOW and social trust}

Research published in recent years shows that CBOW often had negative experiences in the interactions with others. First, many face rejection and stigmatization by the society. In Norway, for example, CBOW were seen as 'children of the enemy' that might even become a danger (Borgersrud 2005) and should be forced to go back to their 'real' home country, Germany. They therefore were socially excluded and met with caution and mistrust (Mochmann and Larsen 2008; Ericsson und Ellingsen 2005; Olsen 2005). Another example of such a stigma can be found in northern Uganda, where many children were born in captivity of the Lord's Resistance Army (LRA) to abducted girls and LRA ranks. Those children are often seen as 'symbols of the more than a decade long suffering' (cf. Apio 2007) and blamed for the acts of the LRA by the home community.

Also, the family of $\mathrm{CBOW}$, be it the one of the mother or an adoptive family, is not necessarily a 'safe heaven' where the children find love and support (Ericsson and Ellingsen 2005: 97-98). Again, research from Norway shows that some $\mathrm{CBOW}$ as well as their mothers faced rejection and discrimination within the family. In some families CBOW needed to cope with emotional negligence and physical and sexual abuse by caregivers and 
close relatives (Ericsson and Ellingsen 2005). Often the mothers were themselves confronted with difficulties resulting from the, forced or voluntary, sexual intercourse with the child's father. Especially those mothers might not always be able or willing to protect and support their child (Mochmann 2014: 545; Ericsson and Ellingsen 2005). Often the topic of the child's biological origin is a taboo within the family, as research, e.g. on the Children born of World War II and of the Vietnam War, shows (Drolshagen 2005; Lee and Mochmann 2015: 31). As a consequence, many CBOW learned at a young age to avoid the subject and did not dare to ask further questions (Mochmann and Larsen 2008: 348).

Mochmann (2012) has defined four factors which seem to be relevant and have an impact on the life development of children born of war. These factors - the social/economic, political/juridical, psychological and biological/medical - vary in their existence, interaction, and strength according to the nature on the conflict and its context. Table 1 summarizes the children's experiences, as categorized by Meckel, Mochmann and Miertsch (2016). The table provides some examples of experiences that may be related to the various factors. Such experiences with stigmatization and rejection might hamper a child's identity formation and the development of a positive self-perception. Interviews with Norwegian CBOW show that some children felt ashamed and developed a very low sense of self-worth, even when oblivious of their biological origin (Ericsson and Ellingsen 2005: 104).

As Leary et al. (1995) showed in several experiments on students, exclusion can also lead to a lower sense of self-worth. Children born of war are de facto part of a marginalized population and as such at the edge of society. Children, who experience such a rejection could come to the conclusion, that they are no accepted part of the society and thus not protected by the established system of values. Constantly facing mistrust in their daily lives, they are likely to as well develop mistrust towards society and later internalize this as personal moral values. 
Table 1. Factors to impact onto CBOW's life, according to Meckel et al. (2016)

\begin{tabular}{|c|c|c|c|c|}
\hline \multicolumn{2}{|c|}{ Social/economic factors } & \multirow{2}{*}{$\begin{array}{l}\text { Political/ } \\
\text { juridical factors }\end{array}$} & \multirow{2}{*}{$\begin{array}{l}\text { Psychological } \\
\text { factors }\end{array}$} & \multirow{2}{*}{$\begin{array}{l}\text { Biological/ } \\
\text { medical factors }\end{array}$} \\
\hline Society & Family & & & \\
\hline $\begin{array}{l}\text { Opinion of } \\
\text { public: 'child of } \\
\text { the enemy', } \\
\text { 'bastard' }\end{array}$ & $\begin{array}{l}\text { Rejection of } \\
\text { mother, close } \\
\text { relatives, } \\
\text { stepfather }\end{array}$ & $\begin{array}{l}\text { Loss of } \\
\text { citizenship }\end{array}$ & $\begin{array}{l}\text { Shame, } \\
\text { without } \\
\text { knowing the } \\
\text { reason or } \\
\text { because of } \\
\text { one's } \\
\text { biological } \\
\text { origin }\end{array}$ & Suicide \\
\hline $\begin{array}{l}\text { Teacher, school } \\
\text { mates, } \\
\text { neighbours: } \\
\text { abuse, mobbing, } \\
\text { exclusion }\end{array}$ & $\begin{array}{l}\text { Abuse by } \\
\text { caregivers }\end{array}$ & $\begin{array}{l}\text { Exclusion of } \\
\text { social services }\end{array}$ & $\begin{array}{l}\text { Self- } \\
\text { stigmatization }\end{array}$ & $\begin{array}{l}\text { Consequences of } \\
\text { trauma and abuse }\end{array}$ \\
\hline $\begin{array}{l}\text { Opinions of } \\
\text { experts: mentally } \\
\text { retarded }\end{array}$ & $\begin{array}{l}\text { Transfer of } \\
\text { negative } \\
\text { experience of } \\
\text { the mother to } \\
\text { the child }\end{array}$ & $\begin{array}{l}\text { Dismissal of } \\
\text { mother of jobs } \\
\text { in public } \\
\text { services }\end{array}$ & $\begin{array}{l}\text { Feelings of } \\
\text { guilt }\end{array}$ & Health problems \\
\hline \multicolumn{2}{|c|}{ Poverty, low education } & Deportation & Identity crisis & $\begin{array}{l}\text { Early occupational } \\
\text { disability }\end{array}$ \\
\hline
\end{tabular}

The above considerations lead to the following refinement of our hypotheses on social trust of children born of war:

H1a: Rejection by close caregivers leads to a lower social trust of CBOW.

H1b: Rejection as 'Child of the Enemy' by the society leads to a lower social trust of CBOW.

H2: $\quad$ The relationship between these experiences of rejection and social trust is partially mediated by a lower sense of self-worth. 


\section{Data and Methods}

For the analysis, we used data based on a quantitative study on Norwegian Children Born of World War II, 'Krigsbarn i Norge - psykosomatiske konsekvenser, identitetsutvikling og erfaringer med fordommer - en spørreundersøkelse blant norske krigsbarn' (Norwegian Children born of War - psychosocial consequences, identity formation and experiences with stereotypes). It was conducted with members of the Norwegian CBOW networks, Norges Krigsbarnforbund and Krigsbarnfobundet Lebensborn and the field work took place between July 2014 und May 2015.3 This specific group of $\mathrm{CBOW}$ was born to local mothers and soldiers of the German Wehrmacht and is also named 'Wehrmachtskinder' ('Wehrmachtchildren'; Drolshagen 2005).

In total 83 people participated in the study, corresponding to a response rate of $22 \%$. This rather low response rate might be due to over surveying, given the repeated investigation of the same population. However, it is difficult to make inferences about the concrete reasons here.

CBOW are an often marginalized and so called 'hidden population' (Mochmann, Lee and Stelzl-Marx 2009: 271; Mochmann 2017). For such populations no sampling frame exists, making the usual sampling methods nearly impossible to apply (Heckathron 2002: 11). Therefore, using existing networks of the people affected is one of the few methods existing to reach such a population. For that reason, however, the survey is not representative for all CBOW, but only for a very selective group: it includes those (Norwegian) $\mathrm{CBOW}$ that agreed to talk about their origin and their experiences and who are willing and able to answer direct questions about these. Consequentially, especially CBOW who made extreme (positive or negative) experiences are unlikely to be part of the study. This is an

\footnotetext{
3 The study is part of a cooperation of three projects in Germany, Austria and Norway which used almost an identical questionnaire. Principal investigators are, in alphabetic order, Heide Glaesmer, Marie Kaiser, Philipp Kuwert, Martin Miertsch, Ingvill C. Mochmann, Ketil J. Ødegaard and Barbara Stelzl-Marx.
} 
unavoidable limitation which should be kept in mind when interpreting research on the basis of this survey (Mochmann 2015).

Despite this restriction it is an important project to understand the life of $\mathrm{CBOW}$ since there exist only very few quantitative surveys on this group. While one should be cautious to generalize the results this still is the most suitable data for this purpose until now.

\section{Measurement}

\section{Dependent Variable: Social Trust}

Social trust is understood as one's confidence that people in general are trustworthy. In the survey, a Norwegian translation of the Adult Attachment Scale (Collins and Read 1990) was used. This questionnaire includes a subscale of six items measuring trust. On a scale ranging from 1 (disagree completely) to 5 (agree completely) participants were asked to state their approval of statements such as 'I find it difficult to trust others completely'. A factor analysis showed that all six items load on one factor (explained variance: $47.1 \%$ ). The factor was then recoded into a scale ranging from 1 (very mistrusting) to 5 (very trusting). On average, participants on this scale had a value of $3.57(\mathrm{SD}=1.05)$. Given that all cases come from the same culture, the difficulties related to the radius of trust (Delhey, Newton, Welzel 2011) are unlikely to affect the construct. 
Table 2. Items, communality and factor loadings of social trust

Items

Communality Factor

loadings

\begin{tabular}{|l|l|l|} 
1. I know that others will be there when I need them & .275 & .512
\end{tabular}

2. I am not sure that I can always depend on others to $\quad .619$

$-.776$ be there when I need them (-)

3. People are never there when you need them (-) .255 $-.496$

4. I am comfortable depending on others .186 .441

5. I find it difficult to allow myself to depend on .734 $-.867$ others.(-)

6. I find it difficult to trust others completely. (-)

.692

Source: "Krigsbarn i Norge“

Notes: Original questions from the Adult Attachment Scale, translated to Norwegian in the given study;

Explained Variance 46.1\%; Extraction Method: Principal Axis Factoring; $N=72$

\section{Independent Variable: Rejection by closest caregivers and by the society}

Rejection by close caregivers is likely to be a very formative experience for children. In the questionnaire participants were asked how emotionally accepted they felt by their closest attachment figures during the age of 0 to school start and from school start to the age of 14 . The scale ranged from 1 (strongly accepted) to 5 (strongly rejected). Both items were averaged into one factor 'rejection by closest caregivers' (Spearman-Brown=.885).

Rejection by the society is operationalized by the accusation of being a 'child of the enemy'. As described previously this stigma is closely connected to mistrust that is directed against Children Born of War. In the survey three questions were asked, which represent this aspect, e.g.: 'I had the feeling, that people blamed me and other "Wehrmacht-Children" of the action of the Wehrmacht-soldiers.' Participants could state their agreement on a scale ranging from 1 (don't agree at all) to 4 (agree completely) or they could choose a different option, 'doesn't apply'. Fieldwork reports showed potential misuses of the scales during answering the questions: participants 
did not seem to understand the different meaning of the answer categories 'doesn't apply' and 'don't agree'. More specifically, several participants rather distinguished between a general 'no' or 'yes' and did not use the scale as intended. Therefore, we recoded all items into dummy-variables with 1 summarizing the categories 'agree somewhat' and 'agree completely'. The three items were added up into one index, ranging from 0 (didn't experience any accusation) to 3 (experienced strong accusation). To be able to use as many cases as possible, we also allowed participants who only answered two out of the three questions $(n=5)$. Their answers were first averaged and then rescaled to range from 0 to 3 .

\section{Mediator: Sense of Self-Worth}

The questionnaire includes several items targeting the sense of self-worth. All of those items were referred to the belonging to the group of CBOW. While some targeted the whole group (e.g. 'I was convinced that "Wehrmacht-Children" aren't worth to be supported.'), other statements focused on the person itself (e.g. 'I felt less worthy, because I am a "Wehrmacht-Child".'). All variables refer specifically to the biological origin of the participant. To operationalize the sense of self-worth seven items were used and summarized by a factor analysis ${ }^{4}$. The resulting score was rescaled to vary from 1 (low sense of self-worth) to 5 (high sense of self-worth). The average participant had a value of $3.91(\mathrm{SD}=1.16)$ on this scale, thus a quite high sense of self-worth.

\footnotetext{
4 Participants with missing values on one of the respective variables were excluded from the analysis.
} 
Table 3. Items, communality and factor loadings of self-worth

\section{Items}

\section{Communality Factor-}

loading

1. I feel different and not integrated, due to being a $0.64 \quad 0.8$ 'Wehrmacht-Child'.

2. I was confident, that 'Wehrmacht-Children' are not $0.53 \quad 0.73$ worth to be supported and promoted.

3. I felt inferior, due to being a 'Wehrmacht-Child'. $0.68 \quad 0.82$

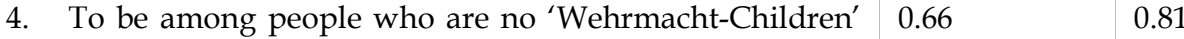
gave me the feeling to be an outsider and deficient.

5. I couldn't accept myself the way I was, due to being a 0.62 'Wehrmacht-Child'.

6. I cannot contribute anything to the society, since I am a $0.33 \quad 0.58$ 'Wehrmacht-Child'.

7. 'Wehrmacht-Children' have nothing to offer, therefore 0.36 only few people were interested to get close to them.

Source: 'Krigsbarn i Norge'

Note: Explained Variance: 55.9\%; Extraction Method: Principal Axis Factoring; N = 68

Own translation

Table 4. Scaling of the variables of interest

\begin{tabular}{l|l|l|l|l}
\hline & $\begin{array}{l}\text { Rejection by } \\
\text { caregivers }\end{array}$ & $\begin{array}{l}\text { Rejection by } \\
\text { society }\end{array}$ & $\begin{array}{l}\text { Sense of self- } \\
\text { worth }\end{array}$ & Social trust \\
\hline Scaling & $\begin{array}{l}\text { 1: strongly } \\
\text { accepted to 5: } \\
\text { strongly } \\
\text { rejected }\end{array}$ & $\begin{array}{l}\text { 0: no experience } \\
\text { of blaming to 3: } \\
\text { strong } \\
\text { experience of } \\
\text { blaming }\end{array}$ & $\begin{array}{l}\text { 1: low sense of } \\
\text { self-worth to 5: } \\
\text { high sense of } \\
\text { self-worth }\end{array}$ & $\begin{array}{l}\text { 1: very } \\
\text { mistrusting to 5: } \\
\text { very trusting }\end{array}$ \\
\hline
\end{tabular}




\section{Method}

To test for the expected mediation effects, we conducted a path analysis using the lavaan-package in R. This method analysis to what extent a total effect an exogenous variable $X$ (in this case rejection by society and close caregivers) on the endogenous variable $Y$ (here social trust) is mediated by a third variable $M$ (here sense of self-worth). The tested model is shown in figure 2 .

Figure 2. Path diagram

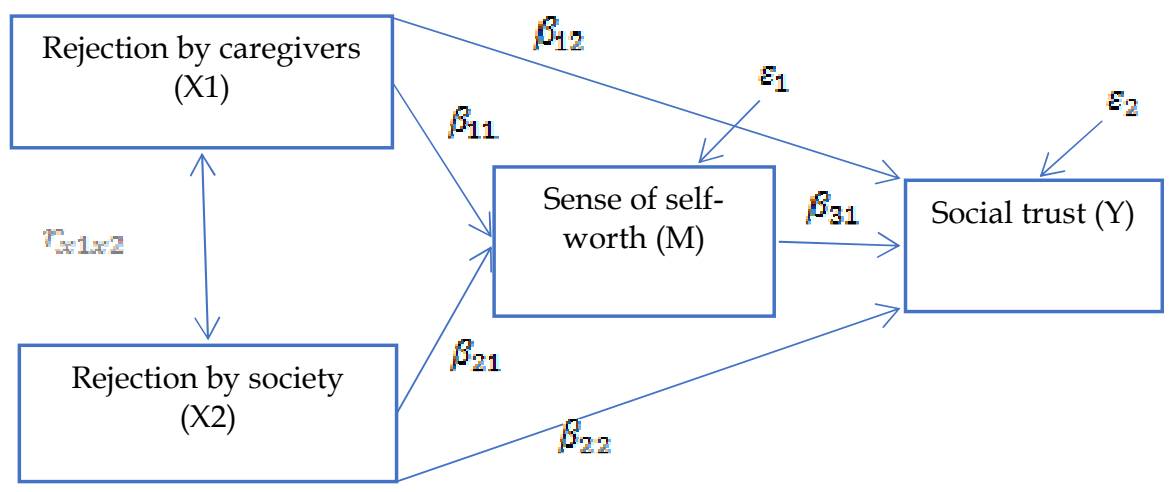

Equations:

$$
\begin{aligned}
& M=\beta_{11} * X 1+\beta_{21} * X 2+\varepsilon_{1} \\
& Y=\beta_{31} * M+\beta_{12} * X 1+\beta_{22} * X 2+\varepsilon_{2}
\end{aligned}
$$

\section{Further remarks on the method and measurement}

As Thompson (2000: 272-273) states, to compute path models a relatively high number of at least 15 or more cases per variable in the analysis is recommendable. After excluding participants with missing values in one of the above-named variables of interest the final sample size consisted of 59 cases. As this is a relatively small sample, we had to refrain from including potentially confounding variables. This has to be taken into account when 
interpreting the results. One should also consider the small sample size when reading the significance levels. Moreover, generalizations may be difficult outside the target group of this study, and significance levels are provided rather as mere indications for strength of the associations we describe.

To ensure robustness of the results, simple OLS models were computed as well. They include social trust as dependent variable, several confounders (age, gender), the mediator, and the two independent variables, in separated models to avoid multicollinearity. Education was also considered as potential confounder. Unfortunately, the measurement in the database does not allow including education in the models, given the very high number of unclear answers.

For the factor analyses which were conducted to estimate the factors trust and sense of self-worth participants with missing values on one of the respective variables were excluded. This differs from the approach used in a similar analysis (Meckel, Mochmann and Miertsch 2016). To avoid further decreasing the already small sample size, the approach chosen then was to impute missing values by the average before the factor analyses. The path analysis then revealed a very surprising result: in the estimated path analysis, an indirect effect of the rejection by the close caregivers was found whereas the total effect was not significant (Meckel, Mochmann and Miertsch 2016: 175). This was assumed to be due to the low sample size (Fritz and MacKinnon 2007).

For this paper, we considered further effects to be responsible for the unexpected results in previous analyses. We thus did further in-depth analyses on the data, such as examining on participants with missing values on one of the respective variables used in the factor analyses. Thereby we compared the average value of those who answered all relevant questions with those who did not. This revealed a potential bias: Participants with missing values, inferring from how they answered to other questions, appeared to be somewhat less trusting and lower in their sense of self- 
worth ${ }^{5}$. This leads us to a problematic situation: mean-substitution as imputation method, while never being the ideal method, assumes that data is missing completely at random (Schlomer et al. 2010). As this, concluding from the further examination of the data, is likely not to be the case here mean-substitution should not be used. However, for more appropriate imputation methods, such as the full information maximum likelihood, the sample size is too small (Myrtveit et al. 2001). We therefore followed the suggestion of Myrtveit et al. (2001) for dealing with missing data in regression models with sample sizes of 40 to 100 and did a list wise deletion of participants with missing data. We have to keep in mind though that if data is not missing completely at random this as well will lead to biased results. This seems to be a disadvantage we cannot fully avoid.

Further complications are to be considered. As already mentioned, the list wise approach reduced the sample size from 83 to 59 cases, therefore losing more than a fifth of the sample. For such high levels of missingness Allison (2000) recommends an imputation strategy. However, the dataset does not include enough relevant variables to undertake other imputation strategy than replacing with mean. Therefore, we have repeated the analyses using the replacement by mean. Yet again, as mentioned, this is likely to introduce a bias in the measurements of trust and self-worthiness (i.e. lower values for any of these variables is likely to be more frequent related to missingness), therefore biasing the estimated relationships to the indicators of rejection. Indeed, the results in this case indicate similar effects in terms of sign of the coefficients, but the levels of significance decrease. We interpret such findings as a confirmation that the observed covariances are likely to be reproduced if full information would have been collected from all population. In other words, the relationships we report are quite robust.

\footnotetext{
5 As the size of the groups compared here is at maximum 12, statistical testing seems inappropriate here. A summary can be found in the Appendix.
} 


\section{Results}

Figure 3 shows the result of the path analysis. Rejection, both by caregivers (the standardized coefficient is $\left.\beta_{11}=-.24, p<.02\right)$ as well as by society $\left(\beta_{21}=\right.$ $-.51, p<.001)$ is significantly associated with the sense of self-worth of the participants. More rejection thereby accompanies a lower sense of selfworth, irrespective of its source. However, it seems that the impact of societal marginalization is stronger.

A high sense of self-worth is associated with higher social trust $\left(\beta_{31}=.48, p<.001\right)$. One-unit increase on the scale of lacking self-worth means .5 on the scale of social trust. Recalling that self-worth ranges from 1 to 5 which means that one-point increase is equivalent to a quarter of its scale. Therefore, an increasing of self-worthiness with one fifth of its scale is equivalent with an increase in social trust of about $14 \%$ of its maximal observed variation, or $10 \%$ of the theoretical range of the scale, correspondingly.

Both, the rejection by caregivers and by society are significantly mediated through the sense of self-worth and do not show a significant direct effect on social trust. More specifically, the direct effects are low and insignificant (the unstandardized coefficients are -.16 for rejection by caregivers, and -.01 for rejection by society, correspondingly). However, the indirect effects, mediated by the self-worthiness are significant.

Thus, concluding from the given data, there is a total mediation of the relationship between rejection and social trust through the sense of selfworth. As expected there is a significant total effect of rejection by society on social trust (the unstandardized total effect given by $\beta_{22}+\beta_{21} * \beta_{31}$ is $-.26, \mathrm{p}$ $=.04$ ). In other words, a change of one third on the scale of rejection by society (which ranges from 0 to 3 ) leads to .2 change on the scale of trust. Also, the rejection by the caregivers is significantly associated with trust (total effect: $\beta_{12}+\beta_{11} * \beta_{31}=-.279, \mathrm{p}=.028$ ). The model explains almost one-third $(32.5 \%)$ of the total variation in levels of social trust. Such high value stresses once more the strength of the observed co-variations. 
The results remain almost unchanged when the mean-imputation approach is used to deal with missingness. However, in this case, the total effects of rejection on trust become insignificant, despite maintaining their sign. As explained, such effects should be read with caution, given the potential connection between response rates and the dependent variable. The imputation of mean values therefore leads to overestimating of levels of social trust. This makes the mediated relationship towards rejection to look weaker, as reflected in our results.

Figure 3. Results of the path analysis

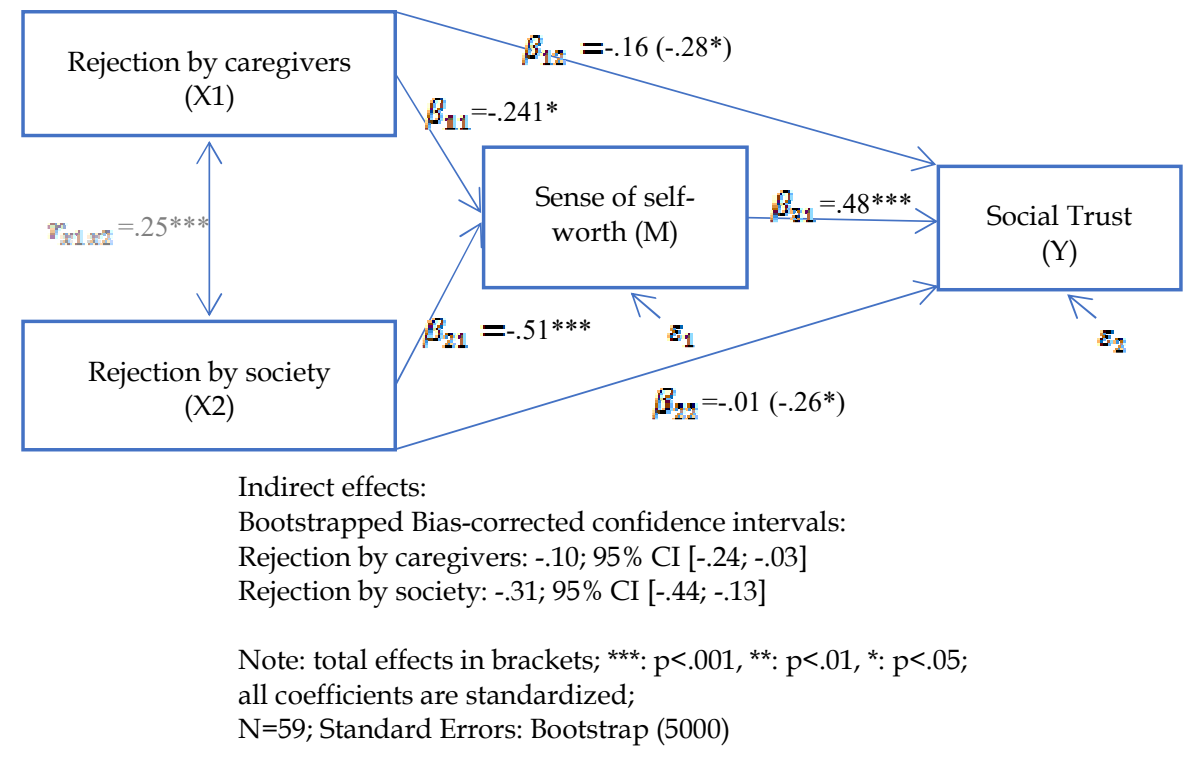

As further robustness check, four separate OLS-regressions were conducted, each including age as well as sex as control variables. The first three analysed trust as dependent variable and included either the sense of self-worth (Model 1), the two rejection measures (Model 2) or all three variables (Model 3). The last examined the sense of self-worth as dependent variable and with the two rejection measures as independent (Model 4).

Overall, results were similar to the presented path analysis. In the model with only sense of self-worth and control variables included, sense of 
self-worth was significantly related to trust: those with less sense of selfworth showed a lower level of trust $\left(\beta=.64^{6}, \mathrm{p}<.001\right)$. Model 2 showed a significant association between the rejection of the society and trust $(\beta=-.3$, $\mathrm{p}=.3$ ) whereas rejection by the caregivers had only a marginal significant impact $(\beta=-.23, \mathrm{p}=.09)$. Model 3 revealed only a significant connection between sense of self-worth and trust $(\beta=.6, \mathrm{p}<.001)$, whereas both rejection measures were not significant. This indicates what has already been shown in the path analysis. Lastly Model 4 shows, similar to the path analysis, that the sense of self-worth was significantly connected to the rejection by the society $(\beta=.47, \mathrm{p}<.001)$ and by the caregivers $(\beta=.26, \mathrm{p}=.03)$.

Neither age nor sex was found to be confounding with respect to trust $^{7}$. Age, however, was marginally significantly connected to the sense of self-worth: the older a person was, the lower was their sense of self-worth ( $\beta$ $=-.07, \mathrm{p}=.09$ ). Unfortunately, it is unclear whether the relation results from aging or from being born earlier and thus experiencing more socialization during wartime and immediately after.

\section{Discussion}

This paper aimed to gain a better understanding of the connection between negative experiences of 'Wehrmacht'-children with rejection and their trust in other people. Thereby the sense of self-worth was expected to be a relevant mediator between rejection-experiences and trust. The conducted analyses indicate that especially experiences with rejection by the society seem to be connected to a low sense of self-worth. The rejection by the caregivers seems as well to be relevant; however, for this association evidence is smaller. Furthermore, low sense of self-worth is significantly

\footnotetext{
${ }^{6}$ Standardized regression coefficients

${ }^{7}$ For the case of Norwegian general population, existing studies are not very conclusive, but seem not to contradict our results. Sivesind et al. (2013) also report the age group we refer to as being homogenous with respect to trust. However, they find a significant effect from gender, with women displaying higher social trust as compared to men. In turn, Wollebæk \& Selle (2003) found no age or gender impact on social trust.
} 
connected to low trust. Thus, the sense of self-worth appears to be an important mediator. In fact, differently from the expected partial mediation, the sense of self-worth seems to fully mediate the relationship.

However, several limitations need to be taken into account which make an extensive interpretation unappropriated. Especially, the small number of participants is to name here. Also, general limitations with regard to the research on $\mathrm{CBOW}$ and 'Wehrmacht'-children specifically need to be considered. As discussed when the data was introduced, it is only possible to research on a very selective group of those (now adult) children, namely those which can be reached through specific networks and who are willing to participate in such a study. As all of them are by now around the age of 70, memory biases will have affected the answers given by the participants. Additionally, our analyses suffer from potential endogeneity, since all variables were measured at the same time and reversed causality or joint dependency upon an omitted cause is possible. With the limited resources given the small sample size, and the existing data, one cannot overcome this barrier. Therefore, we interpret the results as covariances, keeping in mind that a causal explanation exists, but it cannot be proven with currentlyavailable data.

Overall, there are indications that experiences of rejection, especially those by the society, shape the way 'Wehrmacht'-children perceive themselves up to a high age. Those who have such experiences seem to see themselves at the margins of society. This again is connected to higher mistrust. The here presented analyses should however only be understood as a first step. With consideration of the limitations of this research, many more studies need to be conducted to underpin the found relation. As the same questionnaire was conducted in Germany as well as Austria one obvious next step is to use this data in order to replicate the presented analyses. Taking into account the difficulties in conducting quantitative studies on hidden populations such as Children born of War, additionally qualitative studies, which examine experiences with rejection, sense of selfworth and trust should be conducted. To gain a better understanding of the 
hypothesized and tested relationship of these three constructs in general further societal groups and the general population should be researched.

For the moment, with existing data, and considering all robustness checks we have done, we are confident that reported findings hold true. $\mathrm{CBOW}$ are likely to experience lower social trust when they experienced rejection by caregivers or by the society and in this relationship the sense of self-worth plays a strong role. The results from this sample of old CBOW, originated in the WWII, and located in a rather hostile post-war society, may allow drawing learnings for nowadays $\mathrm{CBOW}$, in more recent (post-) conflicts such as Bosnia, Kosovo, Ossetia, Afghanistan, Syria, Rwanda, etc. To deal with $\mathrm{CBOW}$ integration national and international actors need to consider support systems to encounter rejection of $\mathrm{CBOW}$ during and after a conflict (SINTER and GESIS 2016). Failure to properly address these issues may result in long term consequences for the affected group, and thereby indirectly for the whole society as social trust is one of the important pillars for sustaining peace.

\section{Acknowledgement}

We would like to thank Krigsbarnforbundet Lebensborn E.V. and Norges Krigsbarnforbund (NKBF) for their cooperation in carrying out this survey.

\section{Approval}

The study was approved by the responsible ethics commission (REK nord project number: 2013/1455.

\section{Funding}

The project was financially supported by the research grant Günter Jantschek to support the German-Norwegian cooperation in the area of psychosomatic medicine, awarded 2014 by the Deutschen Kollegium für 
Psychosomatische Medizin, as well as the Ellen Margrethe \& Finn Askevolds grant, awarded 2013 by the Norsk Psykoanalytisk Institutt in Oslo.

\section{References:}

Allison, Paul David. 2002. Missing Data. Sage University Papers. Quantitative Applications in the Social Sciences, no. 07-136. Thousand Oaks: Sage Publications.

Apio, Eunice. 2007. "Uganda's forgotten children of war." In Born of War. Protecting Children of Sexual Violence Survivors in Conflict Zones, edited by Charli Carpenter, 94-109. Bloomfield: Kumarian Press.

Barenbaum, Joshua, Vladislav Ruchkin, and Mary Schwab-Stone. 2004. “The psychosocial aspects of children exposed to war: practice and policy initiatives." Journal of Child Psychology and Psychiatry 45(1): 41-62.

Bekkers, René. 2012. "Trust and volunteering: Selection or causation? Evidence from a 4 year panel study". Political Behavior 34(2): 225-247.

Bjørnskov, Christian. 2012. "How does social trust affect economic growth?." Southern Economic Journal 78(4): 1346-1368.

Borgersrud, Lars. 2005. "Meant to be Deported". In Children of World War II. The Hidden Enemy Legacy, edited by Kjersti Ericsson and Eva Simonsen, 71-92. Oxford, New York: Berg.

Collins, Nancy L. and Stephen. J. Read. 1990. “Adult Attachment, Working Models, and Relationship Quality in Dating Couples". Journal of Personality and Social Psychology 58(4): 644-663.

Dearmon, Jacob and Kevin Grier. 2009. "Trust and Development". Journal of Economic Behavior E Organization 71(2): 210-220. doi: 10.1016/j.jebo. 2009.02.011.

Delhey, Jan and Kenneth Newton. 2003. “Who Trusts?: The Origins of Social Trust in Seven Societies". European Societies 5(2): 93-137. doi:10.1080/1461669032000072256.

Delhey, Jan, Kenneth Newton, and Christian Welzel. 2011. "How General is Trust in 'Most People'? Solving the Radius of Trust Problem." American Sociological Review 76(5): 786-807. doi:10.1177/ 0003122411420817.

Drolshagen, Ebba D. 2005. Wehrmachtskinder. Auf der Suche nach dem nie gekannten Vater. München: Droemer Knaur Verlag. 
Ericsson, Kjersti and Ellingsen, Dag. 2005. "Life Stories of Norwegian War Children". In Children of World War II. The Hidden Enemy Legacy, edited by Kjersti Ericsson and Eva Simonsen, 93-112. Oxford \& New York: Berg.

Ericsson, Kjersti, and Eva Simonsen, eds. 2005. Children of World War II: The hidden enemy legacy. Oxford \& New York: Berg.

Ermisch, John, Diego Gambetta, Heather Laurie, Thomas Siedler, and S. C. Noah Uhrig. 2009. "Measuring People's Trust". Journal of the Royal Statistical Society: Series A (Statistics in Society) 172 (4): 749-769. doi:10.1111/j.1467-985X.2009.00591.x.

Frederiksen, Morten. 2012. "Dimensions of Trust: An Empirical Revisit to Simmel's Formal Sociology of Intersubjective Trust". Current Sociology 60(6): 733-750. doi:10.1177/0011392112461800.

Fritz, Matthew S. and David P. MacKinnon. 2007. "Required Sample Size to Detect the Mediated Effect". Psychological Science 18(3): 233-239. doi:10.1111/j.1467-9280.2007.01882.x.

Glanville, Jennifer L., and Pamela Paxton. 2007. "How Do We Learn to Trust? A Confirmatory Tetrad Analysis of the Sources of Generalized Trust". Social Psychology Quarterly 70(3): 230-242.

Goddard, Roger D. 2003. "Relational networks, social trust, and norms: A social capital perspective on students' chances of academic success." Educational evaluation and policy analysis 25(1): 59-74.

Grieg, Kai. 2011. “The War Children of the World”. Norway Bergen: War and Children Identity Project, Bericht (1).

Hardin, Russell 1999. "Do we want trust in government?" In Democracy and Trust, edited by Mark Warren, 22-41. Cambridge \& New York: Cambridge University Press.

Hardin, Russell. 2006. Trust. Key Concepts in the Social Sciences. Cambridge: Polity.

Kleinau, Elke and Ingvill C. Mochmann. 2015. "Wehrmachts- und Besatzungskinder". Aus Politik und Zeitgeschichte 65(16-17): 34-40.

Kleinau, Elke and Ingvill C. Mochmann. 2016 "Kinder des Zweiten Weltkrieges - $\quad$ Stigmatisierung, Ausgrenzung, Bewältigungsstrategien" In Kinder des Zweiten Weltkrieges Stigmatisierung, Ausgrenzung, Bewältigungsstrategien, edited by Elke Kleinau \& Ingvill C. Mochmann, 13-30. Frankfurt/New York: Campus Verlag.

Larsen, Christian Albrekt. 2013. The rise and fall of social cohesion: The construction and de-construction of social trust in the US, UK, Sweden and Denmark. Oxford: Oxford University Press. 
Leary, Mark R., Ellen S. Tambor, Sonja K. Terdal, and Deborah L. Downs. 1995. "Self-Esteem as an Interpersonal Monitor: The Sociometer Hypothesis." Journal of Personality and Social Psychology 68(3): 518-530. doi:10.1037/0022-3514.68.3.518.

Lee, Sabine and Ingvill C. Mochmann. 2015. "Kinder des Krieges im 20. Jahrhundert", In Besatzungskinder - Die Nachkommen alliierter Soldaten in Österreich und Deutschland, edited by Barbara Stelzl-Marx amd Silke Satjukow, 15-38. Kriegsfolgen-Forschung, Band 8. Wien: Böhlau Verlag

Luhmann, Niklas. 2014 [1968]. Vertrauen, 5. Auflage. Konstanz/München: UTB.

Luhmann, Niklas. 1979. Trust and power. Chichester: Willey.

Meckel, Andrea, Ingvill C. Mochmann, and Martin Miertsch. 2016. "Soziales Vertrauen bei norwegischen Wehrmachtskindern." In Kinder des Zweiten Weltkrieges - Stigmatisierung, Ausgrenzung, Bewältigungsstrategien, edited by Elke Kleinau, and Ingvill C. Mochmann, 157-186. Frankfurt/New York: Campus Verlag.

Misztal, Barbara. 2013. Trust in Modern Societies: The Search for the Bases of Social Order. Oxford: Wiley.

Mochmann, Ingvill C. 2008. "Children Born of War." OBETS - Revista de Ciencias Sociales (2): 53-61.

Mochmann, Ingvill C. 2012. "Children born of War: Individual Destinies between Societal and International Responsibilities". Replikk (33): 3239.

Mochmann, Ingvill C. 2014. "Besatzungskinder, tyskerbarn, Amerasians: Krigsbarn i historisk og internasjonal kontekst." Internasjonal Politikk 72 (4): 537-550.

Mochmann, Ingvill C. 2015. Children Born of War: expanding the evidence base on hidden populations. https://www.ukdataservice.ac.uk/media/ 604179/hrdw_mochmann29102015.pdf.

Mochmann, Ingvill C. and Elke Kleinau. 2016. "Kinder des Krieges in Gegenwart und Zukunft - Hilfestellungen und Selbstbemächtigung." In Kinder des Zweiten Weltkrieges - Stigmatisierung, Ausgrenzung, Bewältigungsstrategien, edited by Elke Kleinau, and Ingvill C. Mochmann, 301-308. Frankfurt/New York: Campus Verlag.

Mochmann, Ingvill C. and Stein Ugelvik Larsen. 2008. " "Children Born of War»: The Life Course of Children Fathered by German Soldiers in Norway and Denmark during WWII - Some Empirical Results". Historical Social Research / Historische Sozialforschung 33 (1 (123)): 347363. 
Mochmann, Ingvill C., Sabine Lee, and Barbara Stelzl-Marx. 2009. “The Children of the Occupations Born During the Second World War and Beyond - An Overview". Historical Social Research 34(3): 263-282. doi:10.12759/hsr.34.2009.3.263-282.

Mochmann, Ingvill C. 2017. “A Decade of International and Interdisciplinary Research." Historical Social Research 2017 (42): 320-346.

Möllering, Guido. 2001. "The Nature of Trust: From Georg Simmel to a Theory of Expectation, Interpretation and Suspension". Sociology 35(2): 403-420. doi:10.1177/S0038038501000190.

Newton, Kenneth. 2001. "Trust, Social Capital, Civil Society, and Democracy". International Political Science Review / Revue Internationale de Science Politique 22(2): 201-214.

Olsen, Kåre. 2005. “Under the Care of Lebensborn: Norwegian War Children and their Mothers" In Children of World War II. The Hidden Enemy Legacy, edited by Kjersti Ericsson and Eva Simonsen, 15-34. Oxford \& New York: Berg.

Putnam, Robert D. 1995. "Bowling Alone: America's Declining Social Capital". Journal of Democracy 6(1): 65-78.

Simmel, Georg. 1964. The Sociology of Georg Simmel. New York: The Free Press.

SINTER University of Cologne and GESIS-Leibniz Institute for the Social Sciences. 2016. Key outcomes following the Expert Meeting "Children Born of War in a Comparative Perspective: State of the Art and Recommendations for Future Research and Policy", March 3-4 2016, Cologne, Germany.

<https:// static1.squarespace.com/static/554c5953e4b049566853c20c

/t/5750664e01dbae623ecc812d/1464886878721/Key+Outcomes++CBOW+-+Cologne-Expert-Meeting_March2016.pdf>

Sivesind, Karl Henrik, Tereza Pospíšilová, and Pavol Frič. 2013. “Does volunteering cause trust? A comparison of the Czech Republic and Norway." European Societies 15(1): 106-130. doi:10.1080/14616696. 2012.750732.

Thompson, Bruce. 2000. "Ten commandments of structural equation modeling." In Reading and understanding more multivariate statistics, edited by Laurence G. Grimm and Paul R. Yarnell, 261-284. Washington: American Psychological Association.

Uslaner, Eric M. 1999. "Democracy and Social Capital". In Democracy and Trust, edited by Mark E. Warren, 121-150. New York: Cambridge University Press. 
Uslaner, Eric M. 2002. The moral foundations of trust. New York: Cambridge University Press.

Voicu, Bogdan and Ingvill C. Mochmann. 2014. "Social Trust and Children Born of War". Social Change Review 12(2). doi:10.1515/scr-2015-0005.

Voicu, Bogdan. 2014. "Socialization and Institutionalization Effects on Immigrants' Social Trust". Studia Politica. Romanian Political Science Review XIV(2): 201-220.

Welter, Friederike. 2012. "All you need is trust? A critical review of the trust and entrepreneurship literature." International Small Business Journal 30(3): 193-212.

Wollebaek, Dag and Per Selle. 2003. "Participation and Social Capital Formation: Norway in a Comparative Perspective". Scandinavian Political Studies 26(1): 67-91. doi:10.1111/1467-9477.00080. 


\section{Appendix}

Table 5.

\begin{tabular}{|l|c|c|c|c|c|c|}
\hline & \multicolumn{3}{|c|}{$\begin{array}{c}\text { All questions } \\
\text { answered }\end{array}$} & \multicolumn{3}{c|}{$\begin{array}{c}\text { At least one of the } \\
\text { other questions not } \\
\text { answered }\end{array}$} \\
\hline \multicolumn{1}{|c|}{ Item } & $\mathrm{n}$ & $\mathrm{M}$ & $\mathrm{SD}$ & $\mathrm{n}$ & $\mathrm{M}$ & $\mathrm{SD}$ \\
\hline $\begin{array}{l}\text { 1. I know that others will be there when I need } \\
\text { them }\end{array}$ & 73 & 3.70 & 1.13 & 4 & 3.00 & 1.63 \\
\hline $\begin{array}{l}\text { 2. I am not sure that I can always depend on } \\
\text { others to be there when I need them (-) }\end{array}$ & 73 & 2.25 & 1.13 & 6 & 3.17 & 1.17 \\
\hline $\begin{array}{l}\text { 3. People are never there when you need them } \\
\text { (-) }\end{array}$ & 73 & 1.82 & 0.84 & 3 & 2.00 & 1.00 \\
\hline $\begin{array}{l}\text { 4. I am comfortable depending on others } \\
\text { 5. I find it difficult to allow myself to depend } \\
\text { on others (-) }\end{array}$ & 73 & 3.53 & 1.06 & 3 & 3.33 & 0.58 \\
\hline $\begin{array}{l}\text { 6. I find it difficult to trust others completely (-) } \\
\text { nen }\end{array}$ & 73 & 2.36 & 1.18 & 5 & 2.80 & 0.84 \\
\hline
\end{tabular}


Table 6.

\begin{tabular}{|l|c|c|c|c|c|c|}
\hline & \multicolumn{3}{|c|}{$\begin{array}{c}\text { All questions } \\
\text { answered }\end{array}$} & \multicolumn{3}{c|}{$\begin{array}{c}\text { At least one of the } \\
\text { other questions not } \\
\text { answered }\end{array}$} \\
\hline & $\mathrm{n}$ & $\mathrm{M}$ & $\mathrm{SD}$ & $\mathrm{n}$ & $\mathrm{M}$ & $\mathrm{SD}$ \\
\hline $\begin{array}{l}\text { 1. I feel different and not integrated, due to } \\
\text { being a 'Wehrmacht'-Child. }\end{array}$ & 68 & 1.85 & 1.08 & 12 & 2.75 & 1.42 \\
\hline $\begin{array}{l}\text { 2. I was confident that 'Wehrmacht'- } \\
\text { Children are not worth to be supported and } \\
\text { promoted. }\end{array}$ & 68 & 2.02 & 1.21 & 7 & 2.71 & 1.38 \\
\hline $\begin{array}{l}\text { 3. I felt inferior, due to being a 'Wehrmacht'- } \\
\text { Child. }\end{array}$ & 68 & 2.00 & 1.23 & 10 & 3.30 & 1.25 \\
\hline $\begin{array}{l}\text { 4. To be among people who are no } \\
\text { 'Wehrmacht'-Children gave me the feeling } \\
\text { to be an outsider and deficient. }\end{array}$ & 68 & 1.88 & 1.15 & 9 & 2.44 & 1.42 \\
\hline $\begin{array}{l}\text { 5. I couldn't accept myself the way I was, } \\
\text { due to being a 'Wehrmacht'-Child. }\end{array}$ & 68 & 1.91 & 1.12 & 8 & 1.50 & 0.76 \\
\hline $\begin{array}{l}\text { 6. I cannot contribute anything to the } \\
\text { society, since I am a 'Wehrmacht'-Child. }\end{array}$ & 68 & 1.24 & 0.65 & 8 & 1.25 & 0.46 \\
\hline $\begin{array}{l}\text { 7. 'Wehrmacht'-Children have nothing to } \\
\text { offer, therefore only few people were } \\
\text { interested to get close to them. }\end{array}$ & 68 & 1.71 & 0.96 & 9 & 2.00 & 1.12 \\
\hline
\end{tabular}

